\title{
Synthesis, Structure, and Electrochemical Properties of a Family of 2-(Arylazo)phenolate Complexes of Ruthenium with Unusual C-C Coupling and $\mathrm{N}=\mathrm{N}$ Cleavage
}

\author{
Sarmistha Halder, ${ }^{\dagger}$ Rama Acharyya, ${ }^{\dagger}$ Shie-Ming Peng, ${ }^{\ddagger}$ Gene-Hsiang Lee, ${ }^{\ddagger}$ Michael G. B. Drew, ${ }^{\S}$ and \\ Samaresh Bhattacharya*,† \\ Department of Chemistry, Inorganic Chemistry Section, Jadavpur University, \\ Kolkata 700 032, India, Department of Chemistry, National Taiwan University, \\ Taipei, Taiwan, ROC, and Department of Chemistry, University of Reading, \\ Whiteknights, Reading RG6 6AD, United Kingdom \\ Received April 24, 2006
}

Reaction of 2-(4'-R-phenylazo)-4-methylphenols ( $\mathrm{R}=\mathrm{OCH}_{3}, \mathrm{CH}_{3}, \mathrm{H}, \mathrm{Cl}$, and $\mathrm{NO}_{2}$ ) with [Ru(dmso) $\left.{ }_{4} \mathrm{Cl}_{2}\right]$ affords a family of five ruthenium(III) complexes, containing a 2-(arylazo)phenolate ligand forming a six-membered chelate ring and a tetradentate ligand formed from two 2-(arylazo)phenols via an unusual $\mathrm{C}-\mathrm{C}$ coupling linking the two ortho carbons of the phenyl rings in the arylazo fragment. A similar reaction with 2-(2'-methylphenylazo)-4-methylphenol with $\left[\mathrm{Ru}(\mathrm{dmso})_{4} \mathrm{Cl}_{2}\right]$ has afforded a similar complex, in which one 2-(2'-methylphenylazo)-4-methylphenolate ligand is coordinated forming a six-membered chelate ring, and the other two ligands have undergone the $\mathrm{C}-\mathrm{C}$ coupling reaction, and the coupled species is coordinated as a tetradentate ligand forming a five-membered $\mathrm{N}, \mathrm{O}$-chelate ring, a nine-membered $\mathrm{N}, \mathrm{N}$-chelate ring, and another five-membered chelate ring. Reaction of 2-(2',6'dimethylphenylazo)-4-methylphenol with $\left[\mathrm{Ru}(\mathrm{dmso})_{4} \mathrm{Cl}_{2}\right]$ has afforded a complex in which two 2-(2',6'-dimethylphenylazo)-4-methylphenols are coordinated as bidentate N,O-donors forming five- and six-membered chelate rings, while the third one has undergone cleavage across the $\mathrm{N}=\mathrm{N}$ bond, and the phenolate fragment, thus generated, remains coordinated to the metal center in the iminosemiquinonate form. Structures of four selected complexes have been determined by X-ray crystallography. The first six complexes are one-electron paramagnetic and show rhombic ESR spectra. The last complex is diamagnetic and shows characteristic ${ }^{1} \mathrm{H}$ NMR signals. All the complexes show intense charge-transfer transitions in the visible region and a $R u(I I I)-R u(I V)$ oxidation on the positive side of SCE and a $\mathrm{Ru}(\mathrm{III})-\mathrm{Ru}(\mathrm{II})$ reduction on the negative side.

\section{Introduction}

The chemistry of ruthenium has been receiving considerable current attention, largely because of the interesting redox, photophysical, photochemical, and biological properties exhibited by its complexes. ${ }^{1}$ As all these properties are dictated primarily by the coordination environment around the metal center, complexation of ruthenium by ligands of selected types is of significant importance. For the present study, a group of five 2-(arylazo)phenols $\left(\mathbf{L}_{\mathbf{1}}\right)$ has been selected as the complexing agent. The 2-(arylazo)phenols usually bind to a metal ion, via dissociation of the phenolic

* To whom correspondence should be addressed. Phone: 91 33-24730998. Fax: 91 33-2414-6584. E-mail: samaresh_b@hotmail.com.

† Jadavpur University.

$\doteqdot$ National Taiwan University.

$\S$ University of Reading.

9654 Inorganic Chemistry, Vol. 45, No. 24, 2006 proton, as bidentate N,O-donors forming either five-membered (I) or six-membered (II) chelate rings. ${ }^{2,3}$ Under suitable reaction conditions, in addition to N,O-coordination, orthometalation of the phenyl ring in the arylazo fragment (III) also takes place, leading to the formation of interesting organometallic complexes. ${ }^{4}$ We have been exploring the coordination chemistry of the 2-(arylazo)phenols $\left(\mathbf{L}_{\mathbf{1}}\right)$ and some related ligands, $2,3 \mathrm{~b}, 4,5$ and the present work has originated from our continued interest in this area. The present study was initiated with the primary objective of synthesizing a family of tris chelates of ruthenium using the chosen 2-(arylazo)phenols $\left(\mathbf{L}_{\mathbf{1}}\right)$, and $\left[\mathrm{Ru}(\mathrm{dmso})_{4} \mathrm{Cl}_{2}\right]$ has been utilized as the source of ruthenium for achieving this goal. This particular compound has been selected because of its demonstrated ability to serve as an efficient starting material for 10.1021/ic060689u CCC: $\$ 33.50$ C 2006 American Chemical Society Published on Web 10/20/2006 
the synthesis of homoleptic tris chelates of ruthenium. ${ }^{6}$ Reaction of the 2-(arylazo)phenols $\left(\mathbf{L}_{1}\right)$ and some related ligands with $\left[\mathrm{Ru}(\mathrm{dmso})_{4} \mathrm{Cl}_{2}\right]$ has indeed afforded a group of complexes, where the 2-(arylazo)phenols have not only displayed different modes of binding but also have undergone interesting $\mathrm{C}-\mathrm{C}$ coupling and $\mathrm{N}=\mathrm{N}$ cleavage reactions. The chemistry of all these complexes is reported herein, with special reference to their formation, structure, and spectroscopic and electrochemical properties.<smiles>Cc1ccc(N=Nc2cc(C)ccc2O)cc1</smiles>

$\mathbf{L}_{1}$

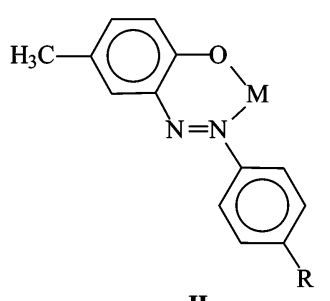

II

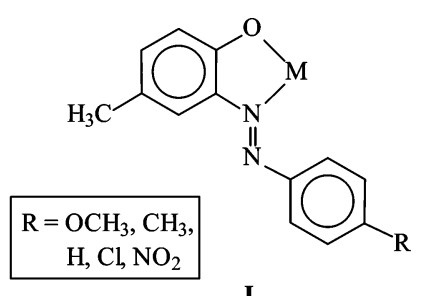

I

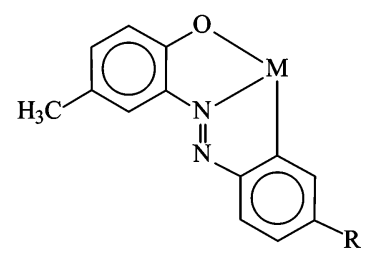

III

\section{Experimental Procedures}

Materials. Commercial ruthenium trichloride was purchased from Arora Matthey, Kolkata, India. 2,6-Dimethylaniline was obtained from Loba, India, and 2-methylaniline, the para-substituted anilines, and $p$-cresol were purchased from S. D. Fine-Chem

(1) (a) Drozdzak, R.; Allaert, B.; Ledoux, N.; Dragutan, I.; Dragutan, V.; Verpoort, F. Coord. Chem. Rev. 2005, 249, 3055. (b) Nazeeruddin, M. K.; Klein, C.; Liska, P.; Grätzel, M. Coord. Chem. Rev. 2005, 249, 1460. (c) Hurst, J. K. Coord. Chem. Rev. 2005, 249, 313. (d) Nazeeruddin, M. K.; Zakeeruddin, S. M.; Lagref, J. J.; Liska, P.; Comte, P.; Barolo, C.; Viscardi, G.; Schenk, K.; Graetzel, M. Coord. Chem. Rev. 2004, 248, 1317. (e) Spiccia, L.; Deacon, G. B.; Kepert, C. M. Coord. Chem. Rev. 2004, 248, 1329. (f) Saito, Y.; Azechi, T.; Kitamura, T.; Hasegawa, Y.; Wada, Y.; Yanagida, S. Coord. Chem. Rev. 2004, 248, 1469. (g) Serli, B.; Zangrando, E.; Gianferrara, T.; Yellowless, L.; Alessio, E. Coord. Chem. Rev. 2003, 245, 73. (h) Clarke, M. J. Coord. Chem. Rev. 2003, 236, 209. (i) Tfouni, E.; Krieger, M.; McGarvey, B. R.; Franco, D. W. Coord. Chem. Rev. 2003, 236, 57. (j) Clarke, M. J. Coord. Chem. Rev. 2002, 232, 69. (k) Che, C. M.; Huang, J. S. Coord. Chem. Rev. 2002, 231, 151. (1) Hartl, F.; Aarnts, M. P.; Nieuwenhuis, H. A.; van Slageren, J. Coord. Chem. Rev. 2002, 230, 106. (m) Gorelsky, S. I.; Lever, A. B. P.; Ebadi, M. Coord. Chem. Rev. 2002, 230, 97. (n) Endicott, J. F.; Schlegel, H. B.; Uddin, M. J.; Seniveratne, D. S. Coord. Chem. Rev. 2002, 229, 95. (o) Yersin, H.; Kratzer, C. Coord. Chem. Rev. 2002, 229, 75. (p) Simonneaux, G.; Maux, P. L. Coord. Chem. Rev. 2002, 228, 43. (q) Ji, L. N.; Zou, X. H.; Liu, J. G. Coord. Chem. Rev. 2001, 216-217, 513. (r) Turki, M.; Daniel, C. Coord. Chem. Rev. 2001, 216-217, 31. (s) Kane-Maguire, N. A. P.; Wheeler, J. F. Coord. Chem. Rev. 2001, 211, 145. (t) Shan, B. Z.; Zhao, Q.; Goswami, N.; Eichhom, D. M.; Rillema, D. P. Coord. Chem. Rev. 2001, 211, 117. (u) Balzani, V.; Juris, A. Coord. Chem. Rev. 2001, 211, 97.

(2) Basuli, F.; Peng, S. M.; Bhattacharya, S. Polyhedron 1998, 18, 391

(3) (a) Rath, R. K.; Nethaji, M.; Chakravarty, A. R. J. Organomet. Chem. 2001, 633, 79. (b) Sui, K.; Peng, S. M.; Bhattacharya, S. Polyhedron 1999, 19, 631. (c) Bhawmik, R.; Biswas, H.; Bandyopadhyay, P. J. Organomet. Chem. 1995, 498, 81. (d) Sinha, C. R.; Bandyopadhyay, D.; Chakravorty, A. J. Chem. Soc., Chem. Commun. 1988, 468. (e) Dyachenko, O. A.; Atovmyan, L. O.; Aldosin, S. M. J. Chem. Soc., Chem. Commun. 1975, 105. (f) Kalia, K. C. Indian J. Chem. 1970, 8 , 1035. (g) Price, R. J. J. Chem. Soc. A 1969, 1296. (h) Jarvis, J. A. J. Acta Crystallogr. 1961, 14, 961.
Limited, India. All other chemicals and solvents were reagent-grade commercial materials and were used as received. $\left[\mathrm{Ru}(\mathrm{dmso})_{4} \mathrm{Cl}_{2}\right]$ was synthesized by following a reported procedure. ${ }^{7}$ The 2-(arylazo)phenols were prepared by coupling respective diazotized aniline with $p$-cresol. Purification of acetonitrile and preparation of tetrabutylammonium perchlorate (TBAP) for electrochemical work were performed as reported in the literature. ${ }^{8}$

Preparations of Complexes. The five 1-R complexes were prepared by following a general procedure. Specific details are given next for a particular complex.

1-H. 2-(Phenylazo)-4-methylphenol ( $\left.\mathbf{L}_{\mathbf{1}}, \mathbf{R}=\mathrm{H}\right)$ (212 mg, 1.00 mmol) was dissolved in ethanol $(40 \mathrm{~mL})$, and to it was added triethylamine $(100 \mathrm{mg}, 1.00 \mathrm{mmol})$. Then, $\left[\mathrm{Ru}(\mathrm{dmso})_{4} \mathrm{Cl}_{2}\right](100$ $\mathrm{mg}, 0.21 \mathrm{mmol}$ ) was added to it. The mixture was then refluxed for $24 \mathrm{~h}^{9}$ to yield a brown solution. The solvent was evaporated, and the solid mass, thus obtained, was subjected to purification by thin-layer chromatography on a silica plate. With benzene as the eluant, a greenish-brown band separated, which was extracted with acetonitrile. Evaporation of this acetonitrile extract gave $\mathbf{1 - H}$ as a brown crystalline solid.

1- $\mathrm{OCH}_{3}$ : Yield: 62\%; Anal. Calcd for $\mathrm{C}_{42} \mathrm{H}_{37} \mathrm{~N}_{6} \mathrm{O}_{6} \mathrm{Ru}$ : C, 61.31; H, 4.50; N, 10.22; Found: C, 60.87; H, 4.11; N, 10.26. 1-CH3: Yield: $60 \%$; Anal. Calcd for $\mathrm{C}_{42} \mathrm{H}_{37} \mathrm{~N}_{6} \mathrm{O}_{3} \mathrm{Ru}$ : C, 65.11; H, 4.78; N, 10.85; Found: C, 65.85; H, 4.72; N, 10.77. 1-H: Yield: $65 \%$; Anal. Calcd for $\mathrm{C}_{39} \mathrm{H}_{31} \mathrm{~N}_{6} \mathrm{O}_{3} \mathrm{Ru}$ : C, 63.93; H, 4.23; N, 11.47; Found: C, 64.15; H, 4.32; N, 11.27. 1-Cl: Yield: 69\%; Anal. Calcd for $\mathrm{C}_{39} \mathrm{H}_{28} \mathrm{~N}_{6} \mathrm{O}_{3} \mathrm{Cl}_{3} \mathrm{Ru}$ : C, 56.01; H, 3.35; N, 10.05; Found: C, 55.25; H, 3.42; N, 10.13. 1-NO ${ }_{2}$ : Yield: 66\%; Anal. Calcd for $\mathrm{C}_{39} \mathrm{H}_{28} \mathrm{~N}_{9} \mathrm{O}_{9} \mathrm{Ru}:$ C, 53.97; H, 3.22; N, 14.53; Found: C, 54.22; H, $3.01 ; \mathrm{N}, 14.27$.

2. This complex was synthesized by following the same procedure using 2-(2'-methylphenylazo)-4-methylphenol $\left(\mathbf{L}_{2}\right)$ instead of 2-(phenylazo)-4-methylphenol $\left(\mathbf{L}_{\mathbf{1}}\right)$. With benzene as the eluant, a deep-brown band separated, which was extracted with acetonitrile. Evaporation of this extract gave $\mathbf{2}$ as a brown crystalline solid. Yield: 55\%; Anal. Calcd for $\mathrm{C}_{42} \mathrm{H}_{37} \mathrm{~N}_{6} \mathrm{O}_{3} \mathrm{Ru}$ : C, 65.11; H, 4.78; N, 10.85; Found: C, 65.22; H, 4.98; N, 10.70 .

3. This complex was synthesized by following the same procedure using 2-(2',6'-dimethylphenylazo)-4-methylphenol $\left(\mathbf{L}_{\mathbf{3}}\right)$ instead of 2-(2'-methylphenylazo)-4-methylphenol $\left(\mathbf{L}_{\mathbf{2}}\right)$. With benzene as the eluant, a deep-violet band separated, which was extracted with acetonitrile. Evaporation of this extract gave 3 as a violet crystalline solid. Yield: 50\%; Anal. Calcd for $\mathrm{C}_{37} \mathrm{H}_{37} \mathrm{~N}_{5} \mathrm{O}_{3} \mathrm{Ru}$ : C, 63.36; H, 5.28; N, 9.99; Found: C, 62.74; H, 5.21; N, 9.92; ${ }^{1} \mathrm{H}$ NMR: $:{ }^{10} 0.88$ (s, 3H); 1.17 (s, 3H); 1.92 (s, 3H); $2.25(\mathrm{~s}, 3 \mathrm{H}) ; 2.33(\mathrm{~s}, 6 \mathrm{H}) ; 2.70(\mathrm{~s}, 3 \mathrm{H}) ; 6.07(\mathrm{~d}, 1 \mathrm{H}, J=7.5) ; 6.26$

(4) (a) Gupta, P.; Dutta, S.; Basuli, F.; Peng, S. M.; Lee, G. H.; Bhattacharya, S. Inorg. Chem. 2006, 45, 460. (b) Gupta, P.; Butcher, R. J.; Bhattacharya, S. Inorg. Chem. 2003, 42, 5405. (c) Acharyya, R.; Basuli, F.; Wang, R. Z.; Mak, T. C. W.; Bhattacharya, S. Inorg. Chem. 2004, 43, 704. (d) Majumder, K.; Peng, S. M.; Bhattacharya, S. J. Chem. Soc., Dalton Trans. 2001, 284. (e) Dutta, S.; Peng, S. M.; Bhattacharya, S. J. Chem. Soc., Dalton Trans. 2000, 4623.

(5) (a) Acharyya, R.; Basuli, F.; Peng, S. M.; Lee, G. H.; Wang, R. Z.; Mak, T. C. W.; Bhattacharya S. J. Organomet. Chem. 2005, 690, 3908. (b) Nag, S.; Gupta, P.; Butcher, R. J.; Bhattacharya S. Inorg. Chem. 2004, 43, 4814. (c) Acharyya, R.; Peng, S. M.; Lee, G. H.; Bhattacharya, S. Inorg. Chem. 2003, 42, 7378.

(6) Das, A.; Peng, S. M.; Lee, G. H.; Bhattacharya, S. New. J. Chem. 2004, 28, 712 .

(7) Evans, I. P.; Spencer, A.; Wilkinson, G. J. Chem. Soc., Dalton Trans. 1973, 204

(8) (a) Sawyer, D. T.; Roberts, J. L., Jr. Experimental Electrochemistry for Chemists; Wiley: New York, 1974; pp 167-215. (b) Walter, M.; Ramaley, L. Anal. Chem. 1973, 45, 165.

(9) Yield of the complex (1-R) drops if a shorter reaction time is allowed. 
Table 1. Crystallographic Data for the 1-Cl, 2, and 3 Complexes

\begin{tabular}{|c|c|c|c|}
\hline & complex 1-Cl & complex 2 & complex 3 \\
\hline empirical formula & $\mathrm{C}_{39} \mathrm{H}_{28} \mathrm{~N}_{6} \mathrm{O}_{3} \mathrm{Cl}_{3} \mathrm{Ru}$ & $\mathrm{C}_{42} \mathrm{H}_{37} \mathrm{~N}_{6} \mathrm{O}_{3} \mathrm{Ru}$ & $\mathrm{C}_{37} \mathrm{H}_{37} \mathrm{~N}_{5} \mathrm{O}_{3} \mathrm{Ru}$ \\
\hline Fw & 836.09 & 774.85 & 700.79 \\
\hline space group & $\begin{array}{l}\text { triclinic, } \\
\qquad P \overline{1}\end{array}$ & $\begin{array}{l}\text { monoclinic, } \\
\qquad P 2_{1} / c\end{array}$ & $\begin{array}{l}\text { monoclinic, } \\
\qquad P 2_{1} / c\end{array}$ \\
\hline$a(\AA)$ & $9.907(12)$ & $9.4178(11)$ & $10.6497(2)$ \\
\hline$b(\AA)$ & $12.804(14)$ & $11.2201(13)$ & $19.4497(5)$ \\
\hline$c(\AA)$ & $15.785(17)$ & $34.892(4)$ & $16.6027(5)$ \\
\hline$\alpha(\operatorname{deg})$ & $97.103(10)$ & 90 & 90 \\
\hline$\beta$ (deg) & $92.560(10)$ & $94.074(2)$ & $106.3570(10)$ \\
\hline$\gamma(\operatorname{deg})$ & $110.502(10)$ & 90 & 90 \\
\hline$V\left(\AA^{3}\right)$ & $1853(4)$ & $3677.7(7)$ & $3299.78(14)$ \\
\hline$Z$ & 2 & 4 & 4 \\
\hline$\lambda(\AA)$ & 0.71073 & 0.71073 & 0.71073 \\
\hline cryst size $\left(\mathrm{mm}^{3}\right)$ & $\begin{array}{c}0.25 \times 0.05 \\
\times 0.05\end{array}$ & $\begin{array}{c}0.15 \times 0.06 \\
\times 0.05\end{array}$ & $\begin{array}{c}0.30 \times 0.23 \\
\times 0.02\end{array}$ \\
\hline$T(\mathrm{~K})$ & 293(2) & 100 & $150(2)$ \\
\hline$\mu\left(\mathrm{mm}^{-1}\right)$ & 0.686 & 0.474 & 0.686 \\
\hline $\mathrm{R} 1^{a}$ & 0.0676 & 0.0607 & 0.0898 \\
\hline $\mathrm{wR} 2^{b}$ & 0.1267 & 0.1646 & 0.2108 \\
\hline $\mathrm{GOF}^{c}$ & 1.04 & 1.00 & 1.117 \\
\hline
\end{tabular}

${ }^{a} \mathrm{R} 1=\sum|| F_{\mathrm{o}}|-| F_{\mathrm{c}}|| / \sum\left|F_{\mathrm{o}}\right|^{b} \mathrm{wR} 2=\left[\sum\left[w\left(F_{\mathrm{o}}{ }^{2}-F_{\mathrm{c}}{ }^{2}\right)^{2}\right] / \sum\left[w\left(F_{\mathrm{o}}{ }^{2}\right)^{2}\right]\right]^{1 / 2}$ ${ }^{c} \mathrm{GOF}=\left[\sum\left[w\left(F_{\mathrm{o}}^{2}-F_{\mathrm{c}}\right)^{2}\right] /(M-N)\right]^{1 / 2}$, where $M$ is the number of reflections and $N$ is the number of parameters refined.

$(\mathrm{s}, 1 \mathrm{H}) ; 6.38(\mathrm{~d}, 1 \mathrm{H}, J=9.1) ; 6.45(\mathrm{~d}, 1 \mathrm{H}, J=7.4) ; 6.65(\mathrm{t}, 1 \mathrm{H}$, $J=7.5) ; 6.91(\mathrm{~d}, 1 \mathrm{H}, J=7.4) ; 7.01-7.18^{*}(\mathrm{~m}, 7 \mathrm{H}) ; 7.37$ (s, 1H); 7.45 (s, 1H); 11.55 (s, 1H).

Physical Measurements. Microanalyses (C, H, and N) were performed using a Heraeus Carlo Erba 1108 elemental analyzer. IR spectra were obtained on a Perkin-Elmer 783 spectrometer with samples prepared as $\mathrm{KBr}$ pellets. Electronic spectra were recorded on a JASCO V-570 spectrophotometer. Mass spectra were recorded with a Micromass LCT electrospray (Qtof Micro YA263) mass spectrometer by an electrospray ionization method. Magnetic susceptibilities were measured using a PAR 155 vibrating sample magnetometer fitted with a Walker Scientific L75FBAL magnet. NMR spectra were recorded in $\mathrm{CDCl}_{3}$ solution with a Bruker AV 300 NMR spectrometer. ESR spectra were recorded with a Varian E--109C X-band spectrometer fitted with a quartz Dewar for measurements at $77 \mathrm{~K}$ (liquid dinitrogen). All ESR spectra were calibrated with the aid of DPPH $(g=2.0037)$. Electrochemical measurements were made using a $\mathrm{CH}$ Instruments model 600A electrochemical analyzer. A platinum disk working electrode, a platinum wire auxiliary electrode, and an aqueous saturated calomel reference electrode (SCE) were used in the cyclic voltammetry experiments. All electrochemical experiments were performed under a dinitrogen atmosphere. All electrochemical data were collected at $298 \mathrm{~K}$ and are uncorrected for junction potentials.

Crystallography. Single crystals of $\mathbf{1 - C l}, \mathbf{1 -} \mathbf{N O}_{2}, \mathbf{2}$, and $\mathbf{3}$ were obtained by slow evaporation of acetonitrile solutions of the respective complexes. Selected crystal data and data collection parameters for complexes $\mathbf{1 - C l , ~ 2 , ~ a n d ~} \mathbf{3}$ are given in Table 1, and those for complex $\mathbf{1}-\mathbf{N O}_{\mathbf{2}}$ are given in Table S1 (Supporting Information). Data were collected, respectively, on a Marresearch Image Plate, a Nonius Kappa CCD diffractometer, an Enraf Nonius CAD-4 diffractometer, and a Nonius Kappa CCD diffractometer, using graphite monochromated Mo K $\alpha$ radiation $(\lambda=0.71073 \AA$ ). $\mathrm{X}$-ray data reduction and structure solution and refinement were done using the SHELXS-97 and SHELXL-97 programs. ${ }^{11}$ The structures were solved by direct methods.

(10) Chemical shifts are given in ppm, and multiplicity of the signals along with the associated coupling constants $(J$ in $\mathrm{Hz})$ are given in parentheses. Overlapping signals are marked with an asterisk.

\section{Results and Discussion}

Five 2-(arylazo)phenols $\left(\mathbf{L}_{1}\right)$ have been used in the present study, differing in the inductive effect of the substituent R, to observe their influence, if any, on the redox potentials of the complexes. Reaction of these ligands with $\left[\mathrm{Ru}(\mathrm{dmso})_{4} \mathrm{Cl}_{2}\right]$ proceeds smoothly in refluxing ethanol in the presence of triethylamine to afford a family of greenish-brown complexes in decent yields. ${ }^{12}$ Magnetic moment and microanalytical data of these complexes have been found to be in good agreement with a tris (2-(arylazo)phenolato)ruthenium(III) formulation. It may be noted here that ruthenium has undergone a oneelectron oxidation during the synthetic reaction, and in view of the relatively low $\mathrm{Ru}(\mathrm{III})-\mathrm{Ru}(\mathrm{II})$ reduction potential displayed by these complexes (vide infra), aerial oxygen seems to have served as the oxidizing agent. To find out the stereochemistry of these complexes, as well as coordination mode of the 2-(arylazo)phenolate ligands in them, the structure of a representative member of this family, viz. that obtained from the reaction with 2-(4'-chlorophenylazo)-4methylphenol $\left(\mathbf{L}_{\mathbf{1}}, \mathrm{R}=\mathrm{Cl}\right)$, has been determined by $\mathrm{X}$-ray crystallography. The structure is shown in Figure 1, and some relevant bond parameters are listed in Table 2 . The structure shows that three 2-(arylazo)phenols are indeed coordinated to ruthenium, via loss of the phenolic proton, but there are interesting differences in their modes of binding. One ligand is coordinated as a bidentate N,O-donor forming a sixmembered chelate ring (Figure 1b). The second ligand is also coordinated as the first one, while the third ligand is coordinated to ruthenium as a N,O-donor forming a fivemembered chelate ring, and an unexpected $\mathrm{C}-\mathrm{C}$ coupling has occurred between these two ligands linking the two ortho carbon atoms on the two phenyl rings in the arylazo fragments (Figure 1c). The coupled species is thus serving as a tetradentate ligand forming a five-membered $\mathrm{N}, \mathrm{O}$-chelate ring, an eight-membered N,N-chelate ring, and a sixmembered N,O-chelate ring (IV). Length of the new $\mathrm{C}-\mathrm{C}$

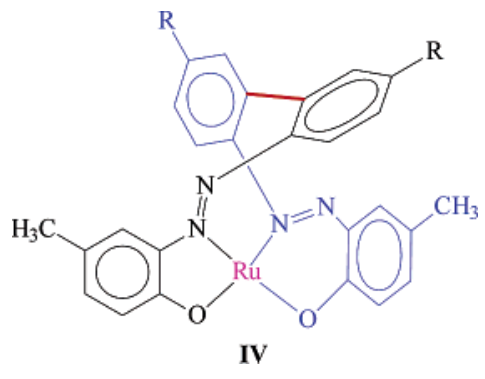

bond, which has formed via the coupling reaction, is found to be normal. ${ }^{13}$ All the $\mathrm{Ru}-\mathrm{N}$ and $\mathrm{Ru}-\mathrm{O}$ distances are quite usual, and so are the $\mathrm{C}-\mathrm{O}$ and $\mathrm{N}-\mathrm{N}$ distances. ${ }^{2,3 \mathrm{~b}, 4,5}$

(11) Sheldrick, G. M. SHELXS-97 and SHELXL-97, Fortran programs for crystal structure solution and refinement; University of Gottingen: Gottingen, Germany, 1997

(12) Besides the isolated products (complexes 1-R, 2, and 3), other uncharacterizable species are also formed during the synthesis of these complexes, which accounts for the observed $(\sim 65 \%)$ yields of these complexes.

(13) (a) Dillon, K. B.; Zorina, N. V.; Yufit, D. S.; Howard, J. A. K. Acta Crystallogr., Sect. E 2006, 62, 104. (b) Robertson, A. J.; Price, D. J. Acta Crystallogr., Sect. E 2005, 61, 2610. 


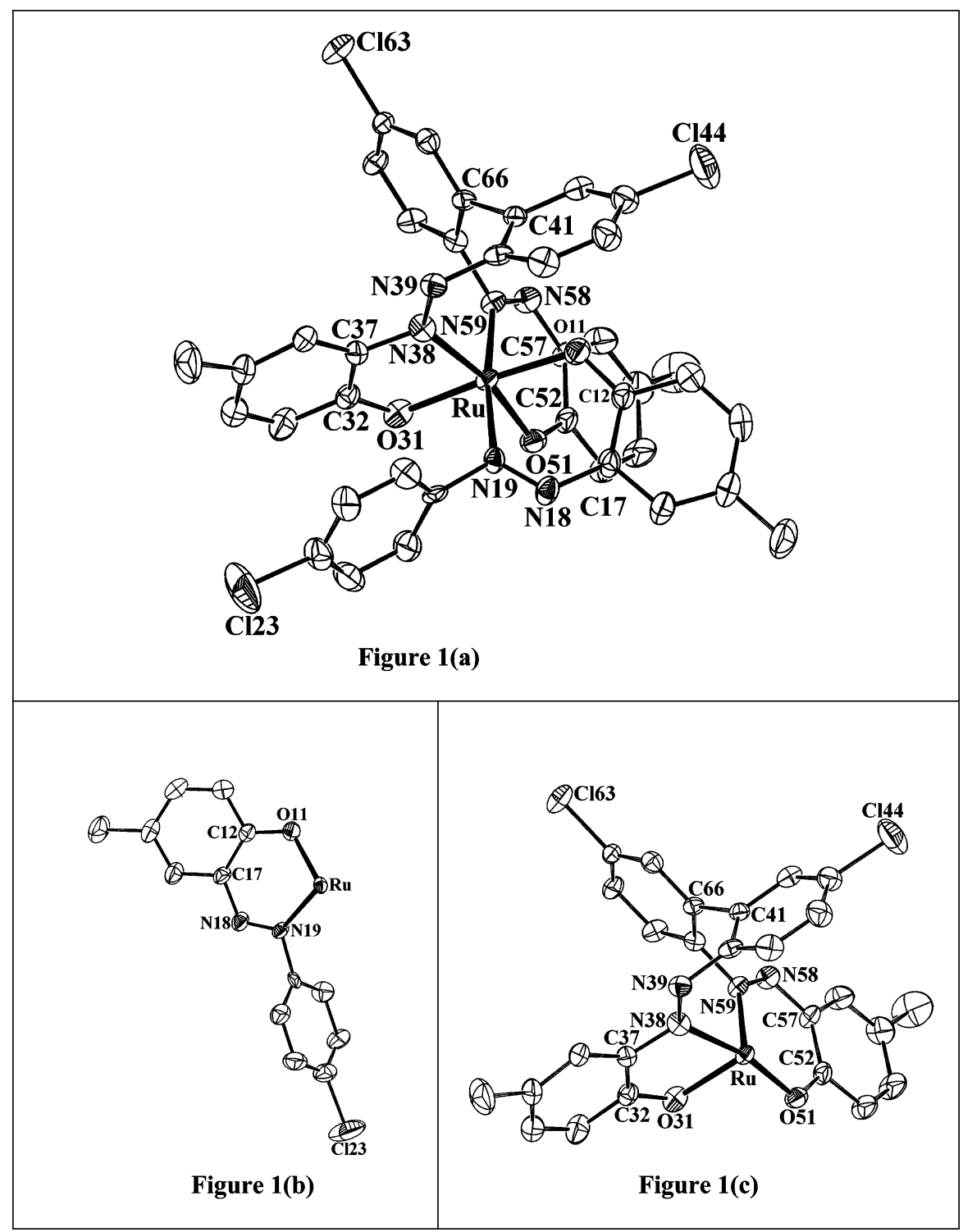

Figure 1. View of (a) the 1-Cl complex, (b) the coordinated 2-(arylazo)phenolate ligand forming a six-membered N,O-chelate ring, and (c) the other two coordinated ligands that have undergone unusual $\mathrm{C}-\mathrm{C}$ coupling.

However, both the $\mathrm{Ru}-\mathrm{N}$ and the $\mathrm{Ru}-\mathrm{O}$ distances in the five-membered chelate ring are slightly longer than the corresponding distances in the six-membered chelate rings. In this complex, ruthenium is nested in a $\mathrm{N}_{3} \mathrm{O}_{3}$ coordination sphere, which is distorted from ideal octahedral geometry as reflected in the bond parameters around the metal center. Considering only the relative dispositions of the coordinated donor atoms, the complex has a meridional geometry, which is very usual for tris chelates of ruthenium(III) containing unsymmetrical bidentate ligands. ${ }^{6}$ It is interesting to note that in the meridional geometry, two ligands always remain mutually cis, and in the present complex, the $\mathrm{C}-\mathrm{C}$ coupling has occurred between these two mutually cis ligands.

The $\mathrm{C}-\mathrm{C}$ coupling between two 2-(arylazo)phenolate ligands, observed in the structurally characterized complex described previously, is very unusual and, to our knowledge, unprecedented. An obvious query that arises from this observation is whether the same $\mathrm{C}-\mathrm{C}$ coupling has also occurred in the other four complexes of this family. As the preliminary characterization (viz. microanalytical, magnetic, spectroscopic, and electrochemical) techniques are found to be unsuitable for unambiguous detection of such a coupling reaction, the structure of another member of this family, viz. that obtained from the reaction with 2-(4'-nitrophenylazo)4-methylphenol $\left(\mathbf{L}_{\mathbf{1}}, \mathrm{R}=\mathrm{NO}_{2}\right)$, has also been determined by X-ray crystallography. The structure (Figure S1, Supporting Information) clearly shows that the same $\mathrm{C}-\mathrm{C}$ coupling has indeed occurred in this complex. All the structural features of this complex (Table S2, Supporting Information) are found to be similar to those observed in the earlier one. These five greenish-brown complexes $(\mathbf{1}$, see Chart 1) therefore represent an unique family of 2-(arylazo)phenolate complexes where the 2-(arylazo)phenolate ligands have undergone an unusual $\mathrm{C}-\mathrm{C}$ coupling. As all the five 1-R complexes have been synthesized similarly and they show similar properties (vide infra), the other three $\mathbf{1}-\mathbf{R}$ ( $\mathrm{R}$ $=\mathrm{OCH}_{3}, \mathrm{CH}_{3}$, and $\mathrm{H}$ ) complexes are assumed to have

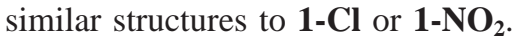


Table 2. Selected Bond Distances and Bond Angels for the 1-Cl, 2, and $\mathbf{3}$ Complexes

\begin{tabular}{|c|c|c|c|}
\hline \multicolumn{4}{|c|}{ Complex 1-Cl } \\
\hline \multicolumn{4}{|c|}{ Bond Distances $(\AA)$} \\
\hline $\mathrm{Ru}-\mathrm{N}(19)$ & $2.059(6)$ & $\mathrm{C}(12)-\mathrm{O}(11)$ & $1.318(7)$ \\
\hline $\mathrm{Ru}-\mathrm{N}(38)$ & $2.093(6)$ & $\mathrm{C}(32)-\mathrm{O}(31)$ & $1.321(7)$ \\
\hline $\mathrm{Ru}-\mathrm{N}(59)$ & $2.032(5)$ & $\mathrm{C}(52)-\mathrm{O}(51)$ & $1.324(7)$ \\
\hline $\mathrm{Ru}-\mathrm{O}(11)$ & $1.990(4)$ & $\mathrm{N}(18)-\mathrm{N}(19)$ & $1.283(7)$ \\
\hline $\mathrm{Ru}-\mathrm{O}(31)$ & $2.021(4)$ & $\mathrm{N}(38)-\mathrm{N}(39)$ & $1.295(7)$ \\
\hline $\mathrm{Ru}-\mathrm{O}(51)$ & $1.982(5)$ & $\mathrm{N}(58)-\mathrm{N}(59)$ & $1.287(7)$ \\
\hline & & $C(41)-C(66)$ & $1.508(7)$ \\
\hline \multicolumn{4}{|c|}{ Bond Angles (deg) } \\
\hline $\mathrm{N}(19)-\mathrm{Ru}-\mathrm{N}(59)$ & $172.35(19)$ & $\mathrm{N}(19)-\mathrm{Ru}-\mathrm{O}(11)$ & $87.88(17)$ \\
\hline $\mathrm{N}(38)-\mathrm{Ru}-\mathrm{O}(51)$ & $168.41(18)$ & $\mathrm{N}(38)-\mathrm{Ru}-\mathrm{O}(31)$ & $79.06(18)$ \\
\hline $\mathrm{O}(11)-\mathrm{Ru}-\mathrm{O}(31)$ & $176.25(16)$ & $\mathrm{N}(59)-\mathrm{Ru}-\mathrm{O}(51)$ & $90.82(18)$ \\
\hline \multicolumn{4}{|c|}{ Complex 2} \\
\hline \multicolumn{4}{|c|}{ Bond Distances $(\AA)$} \\
\hline $\mathrm{Ru}-\mathrm{N}(2)$ & $2.033(3)$ & $\mathrm{C}(1)-\mathrm{O}(1)$ & $1.308(4)$ \\
\hline $\mathrm{Ru}-\mathrm{N}(3)$ & $2.067(3)$ & $\mathrm{C}(15)-\mathrm{O}(2)$ & $1.332(4)$ \\
\hline $\mathrm{Ru}-\mathrm{N}(5)$ & $2.097(3)$ & $\mathrm{C}(29)-\mathrm{O}(3)$ & $1.310(4)$ \\
\hline $\mathrm{Ru}-\mathrm{O}(1)$ & $1.975(2)$ & $\mathrm{N}(1)-\mathrm{N}(2)$ & $1.267(5)$ \\
\hline $\mathrm{Ru}-\mathrm{O}(2)$ & $1.985(3)$ & $\mathrm{N}(3)-\mathrm{N}(4)$ & $1.262(5)$ \\
\hline $\mathrm{Ru}-\mathrm{O}(3)$ & $2.015(3)$ & $\mathrm{N}(5)-\mathrm{N}(6)$ & $1.278(4)$ \\
\hline \multicolumn{4}{|c|}{ Bond Angles (deg) } \\
\hline $\mathrm{N}(2)-\mathrm{Ru}-\mathrm{N}(3)$ & 169.19(11) & $\mathrm{N}(2)-\mathrm{Ru}-\mathrm{O}(1)$ & $90.43(10)$ \\
\hline $\mathrm{N}(5)-\mathrm{Ru}-\mathrm{O}(2)$ & $171.74(9)$ & $\mathrm{N}(3)-\mathrm{Ru}-\mathrm{O}(2)$ & $81.17(10)$ \\
\hline $\mathrm{O}(1)-\mathrm{Ru}-\mathrm{O}(3)$ & $175.04(10)$ & $\mathrm{N}(5)-\mathrm{Ru}-\mathrm{O}(3)$ & $78.73(11)$ \\
\hline \multicolumn{4}{|c|}{ Complex 3} \\
\hline \multicolumn{4}{|c|}{ Bond Distances $(\AA)$} \\
\hline $\mathrm{Ru}-\mathrm{N}(1)$ & $2.039(7)$ & $\mathrm{C}(1)-\mathrm{O}(1)$ & $1.318(7)$ \\
\hline $\mathrm{Ru}-\mathrm{N}(3)$ & $2.107(8)$ & $\mathrm{C}(16)-\mathrm{O}(2)$ & $1.321(7)$ \\
\hline $\mathrm{Ru}-\mathrm{N}(5)$ & $1.941(7)$ & $\mathrm{C}(31)-\mathrm{O}(3)$ & $1.324(7)$ \\
\hline $\mathrm{Ru}-\mathrm{O}(1)$ & $2.009(6)$ & $\mathrm{N}(1)-\mathrm{N}(2)$ & $1.421(7)$ \\
\hline $\mathrm{Ru}-\mathrm{O}(2)$ & $2.011(6)$ & $\mathrm{N}(3)-\mathrm{N}(4)$ & $1.295(7)$ \\
\hline $\mathrm{Ru}-\mathrm{O}(3)$ & $2.059(6)$ & & \\
\hline \multicolumn{4}{|c|}{ Bond Angles (deg) } \\
\hline $\mathrm{N}(1)-\mathrm{Ru}-\mathrm{N}(3)$ & $163.5(3)$ & $\mathrm{N}(1)-\mathrm{Ru}-\mathrm{O}(1)$ & $91.5(3)$ \\
\hline $\mathrm{N}(5)-\mathrm{Ru}-\mathrm{O}(2)$ & $173.9(3)$ & $\mathrm{N}(3)-\mathrm{Ru}-\mathrm{O}(2)$ & $79.1(3)$ \\
\hline $\mathrm{O}(1)-\mathrm{Ru}-\mathrm{O}(3)$ & $178.0(2)$ & $\mathrm{N}(5)-\mathrm{Ru}-\mathrm{O}(3)$ & $79.7(3)$ \\
\hline
\end{tabular}

The exact mechanism of the observed $\mathrm{C}-\mathrm{C}$ bond formation is not completely clear to us. However, the speculated sequences shown in Scheme 1 seem plausible. In the initial step, an intermediate $\mathbf{A}$ is believed to be formed, in which two 2-(arylazo)phenolate ligands are coordinated to ruthenium-one as a bidentate N,O-donor forming a six-membered chelate ring and the other as a tridentate $\mathrm{C}, \mathrm{N}, \mathrm{O}$-donor. Displacement of the coordinated dmso in $\mathbf{A}$ by the azonitrogen of another 2-(arylazo)phenolate ligand then takes place generating a second intermediate B. Coordination of the phenolate-oxygen brings about dissociation of the $\mathrm{Ru}-\mathrm{C}$ bond, which is followed by nucleophilic attack of the resulting carbanion to the ortho carbon of the pendant phenyl ring resulting in the formation of the $\mathrm{C}-\mathrm{C}$ bond via elimination of a hydride. It is relevant to mention here that metal-bound arylazo fragments are known to undergo facile nucleophilic substitution at the ortho position of the pendent phenyl ring. ${ }^{14}$

To sort out any steric influence behind the observed $\mathrm{C}-\mathrm{C}$ coupling, we have carried out some modeling studies, ${ }^{15}$ where the observed meridional stereochemistry of the $\mathbf{1 - R}$

\section{Chart 1}
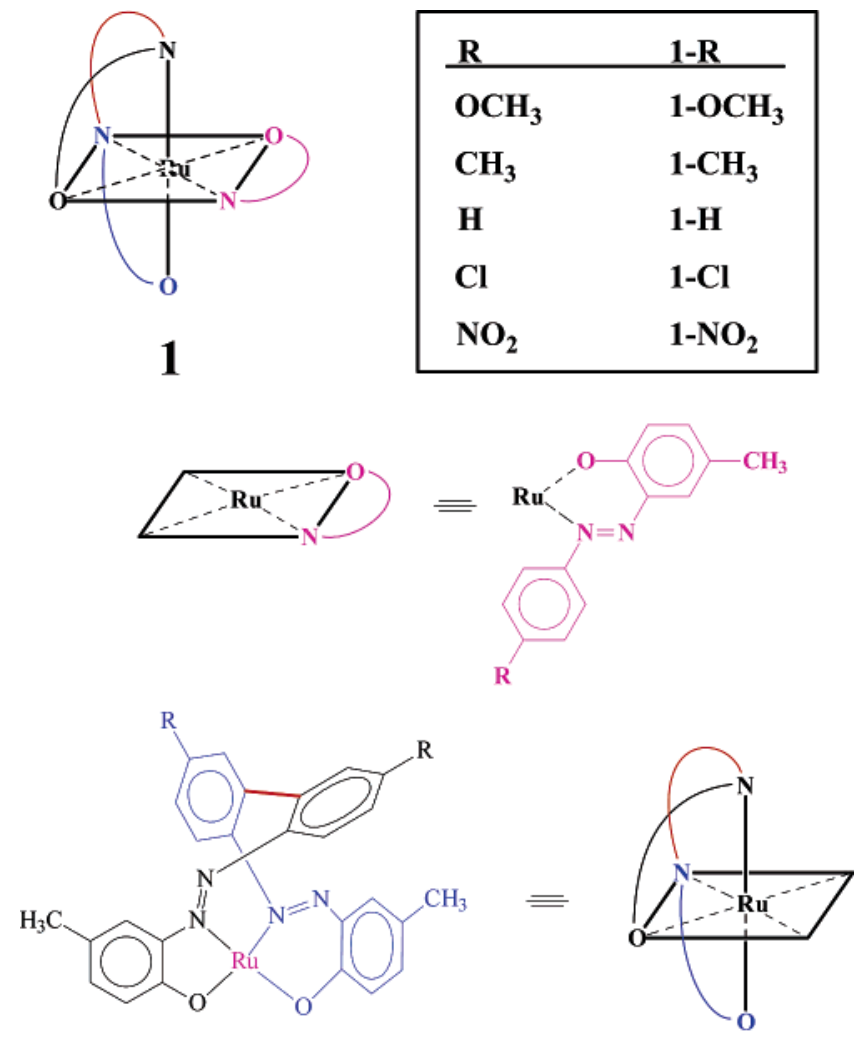<smiles>Cc1ccc(O)c(/N=N/c2ccccc2C)c1</smiles><smiles>Cc1ccc(O)c(/N=N/c2c(C)cccc2C)c1</smiles>

$\mathbf{L}_{3}$

complexes has been retained. As stated previously, in the meridional geometry, two coordinated ligands remain mutually cis by default, and we shall be particularly referring to these two mutually cis ligands with reference to the $\mathrm{C}-\mathrm{C}$ bond formation. Our modeling studies show (Figure S2, Supporting Information) that the size of the chelate rings formed by the two cis ligands plays a very important role in the $\mathrm{C}-\mathrm{C}$ coupling. If all three 2-(arylazo)phenolate ligands coordinate to the metal center forming only six-membered chelate rings, then the two pendant phenyl rings of the two cis ligands can never come close enough so as to lead to the formation of a $\mathrm{C}-\mathrm{C}$ bond (Figure S2a). But, if any one of the two cis ligands forms a five-membered chelate ring, then the two pendant phenyl rings are bound to come in close proximity (Figure $\mathrm{S} 2 \mathrm{~b}$ ) during their rotation around the $\mathrm{N}-\mathrm{C}$

(14) (a) Saha, A.; Majumdar, P.; Goswami, S. J. Chem. Soc., Dalton Trans. 2000, 1703. (b) Saha, A.: Ghosh, A. K.; Majumdar, P.; Mitra, K.; Mondal, S.; Rajak, K. K.; Falvello, L. R.; Goswami, S. Organometallics 1999, 18, 3772. (c) Santra, B. K.; Thakur, G. A.; Ghosh, P.; Pramanik, A.; Lahiri, G. K. Inorg. Chem. 1996, 35, 3050. (d) Bandyopadhyay, P.; Bandyopadhyay, D.; Chakravorty, A.; Cotton, F. A.; Falvello, L. R.; Han, S. J. Am. Chem. Soc. 1983, 105, 6327.

(15) (a) Mealli, C.; Proserpio, D. M. CACAO Version 4.0; Firenze, Italy, 1994. (b) Mealli, C.; Proserpio, D. M. J. Chem. Educ. 1990, 67, 399. 
Scheme 1. Probable Steps for Formation of the 1-R Complexes ${ }^{a}$
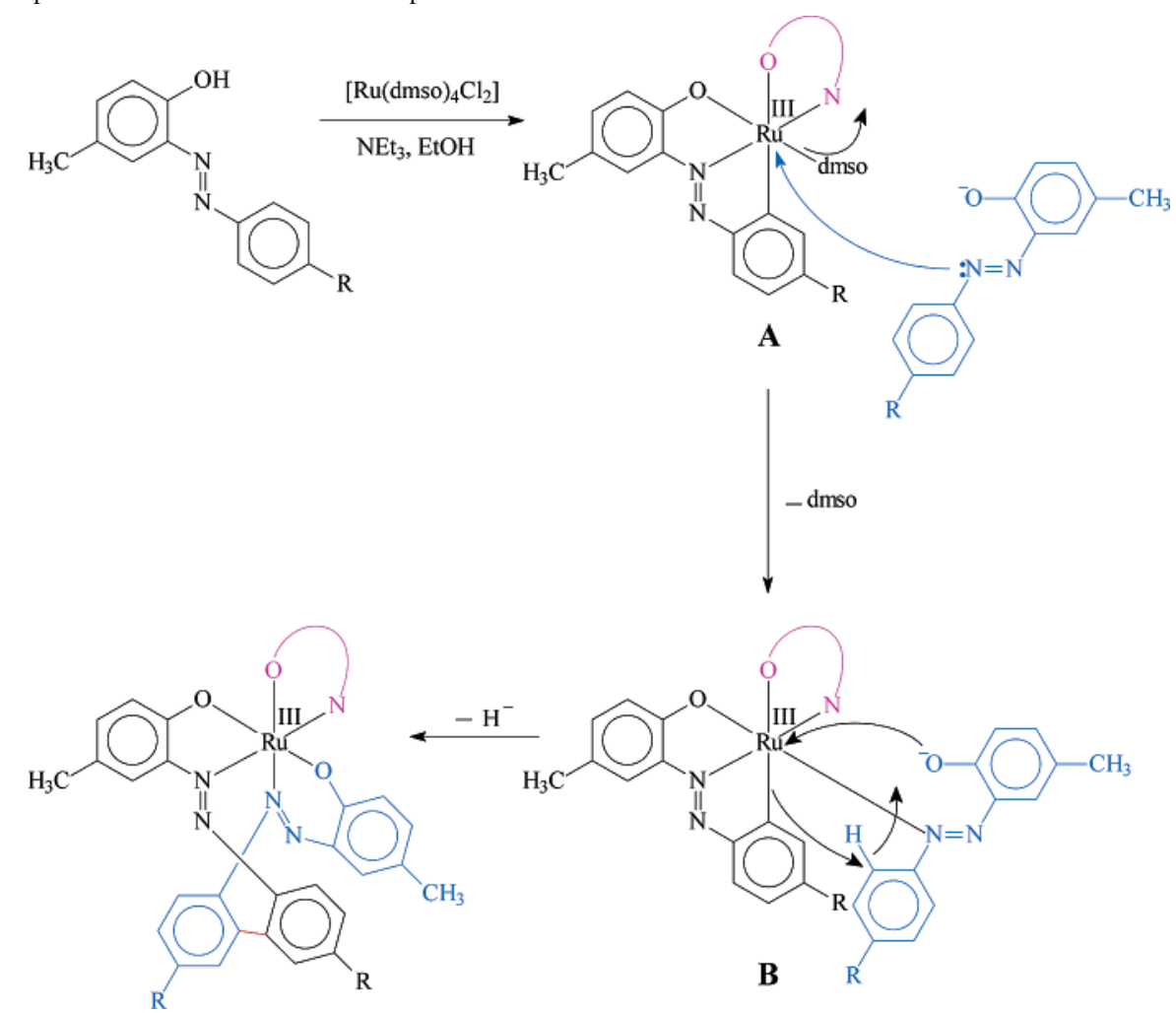

${ }^{a}$ In $\mathbf{A}, \mathbf{B}$, and the final product, the 2-(arylazo) phenolate ligand forming a six-membered ring is shown in pink.

single bond facilitating the $\mathrm{C}-\mathrm{C}$ coupling. Hence, the observed $\mathrm{C}-\mathrm{C}$ coupling seems to result from a combination of electronic and steric effects. It may be noted here that transition metal mediated $\mathrm{C}-\mathrm{C}$ bond formation reactions are of considerable current interest. ${ }^{16}$

Encouraged by the observed $\mathrm{C}-\mathrm{C}$ coupling between the two mutually cis 2-(arylazo)phenolate ligands in the $\mathbf{1 - R}$

(16) (a) Albeniz, A. C.; Espinet, P.; Perez-Mateo, A.; Nova, A.; Ujaque, G. Organometallics 2006, 25, 1293. (b) Esteruelas, M. A.; Gonzalez, A. I.; Lopez, A. M.; Olivan, M.; Onate, E. Organometallics 2006, 25, 693. (c) Li, X.; Schopf, M.; Stephan, J.; Kipke, J.; Harms, K.; Sundermeyer, J. Organometallics 2006, 25, 528. (d) Ogo, S.; Takebe, Y.; Uehara, K.; Yamazaki, T.; Nakai, H.; Watanabe, Y.; Fukuzumi, S. Organometallics 2006, 25, 331. (e) Daquino, C.; Foti, M. C. Tetrahedron 2006, 62, 1536. (f) Schaefer, M.; Wolf, J.; Werner, H. J. Chem. Soc., Dalton Trans. 2005, 1468. (g) Werner, H.; Muench, G.; Laubender, M. Inorg. Chim. Acta 2005, 358, 1510. (h) Tanaka, K.; Miyazawa, A.; Hiate, A.; Tashiro, M.; Saisyo, T.; Okabe, R.; Kohno, K.; Yamato, T. J. Chem. Res. 2005, 495. (i) De Felice, V.; De Renzi, A.; Fraldi, N.; Roviello, G.; Tuzi, A. J. Organomet. Chem. 2005, 690, 2035. (j) Chin, C. S.; Lee, H.; Eum, M. S. Organometallics 2005, 24 4849. (k) Esteruelas, M. A.; Lopez, A. M. Organometallics 2005, 24 , 3584. (l) Cadierno, V.; Diez, J.; Garcia-Alvarez, J.; Gimeno, J. Organometallics 2005, 24, 2801. (m) Werner, H. Organometallics 2005, 24, 1036. (n) Maier, P.; Redlich, H.; Richter, J. Tetrahedron: Asymmetry 2005, 16, 3848. (o) Fleischer, H.; Schollmeyer, D. Z. Naturforsch. B 2005, 60, 1083. (p) Trifonov, A. A.; Fedorova, E. A.; Fukin, G. K.; Druzhkov, N. O.; Bochkarev, M. N. Angew. Chem., Int. Ed. 2004, 43, 5045. (q) Noveski, D.; Braun, T.; Neumann, B.; Stammler, A.; Stammler, H. G. J. Chem. Soc., Dalton Trans. 2004, 4106. (r) Schmid, R.; Kirchner, K. Eur. J. Inorg. Chem. 2004, 2609. (s) Li, X.; Appelhans, L. N.; Faller, J. W.; Crabtree, R. H. Organometallics 2004, 23, 3378. (t) Navarro, J.; Sola, E.; Martin, M.; Dobrinovitch, I. T.; Lahoz, F. J.; Oro, L. A. Organometallics 2004, 23, 1908. (u) Werner, H.; Mahr, N.; Schneider, M. E.; Bosch, M.; Wolf, J. Polyhedron 2004, 23, 2645. (v) Zippel, T.; Arndt, P.; Ohff, A.; Spannenberg, A.; Kempe, R.; Rosenthal, U. Organometallics 1998, $17,4429$. complexes, we planned to study a similar reaction with a slightly modified 2-(arylazo)phenol, viz. 2-(2'-methylphenylazo)-4-methylphenol $\left(\mathbf{L}_{2}\right)$. In this ligand, one ortho position of the phenyl ring in the arylazo fragment is blocked by a methyl group, while the other ortho position is still unsubstituted. So, in case a similar $\mathrm{C}-\mathrm{C}$ coupling reaction takes place as before, it would involve elimination of $\mathrm{H}_{2}$ or $\mathrm{CH}_{4}$ or $\mathrm{C}_{2} \mathrm{H}_{6}$. To sort this out, the reaction of ligand $\mathbf{L}_{2}$ with $\left[\mathrm{Ru}(\mathrm{dmso})_{4} \mathrm{Cl}_{2}\right]$ has been carried out similarly as before, which has afforded a brown complex (2). Mass spectrum of complex 2 (Figure S3, Supporting Information) indicates coordination of three ligands to ruthenium without the loss of any methyl fragment. The identity of complex $\mathbf{2}$ has been revealed by its structure determination by X-ray crystallography. The structure (Figure 2) shows that, as observed in the $\mathbf{1 - R}$ complexes, a similar $\mathrm{C}-\mathrm{C}$ coupling has also taken place in this complex via elimination of $\mathrm{H}_{2}$. However, the coupled species is coordinated to ruthenium in a slightly different fashion (V). One 2-(2'-methylphenylazo)-4-meth-

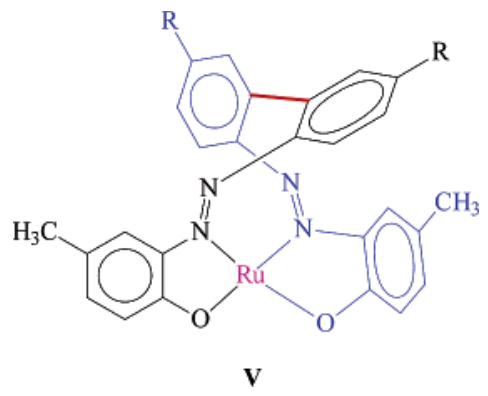

ylphenolate ligand is coordinated forming a six-membered 


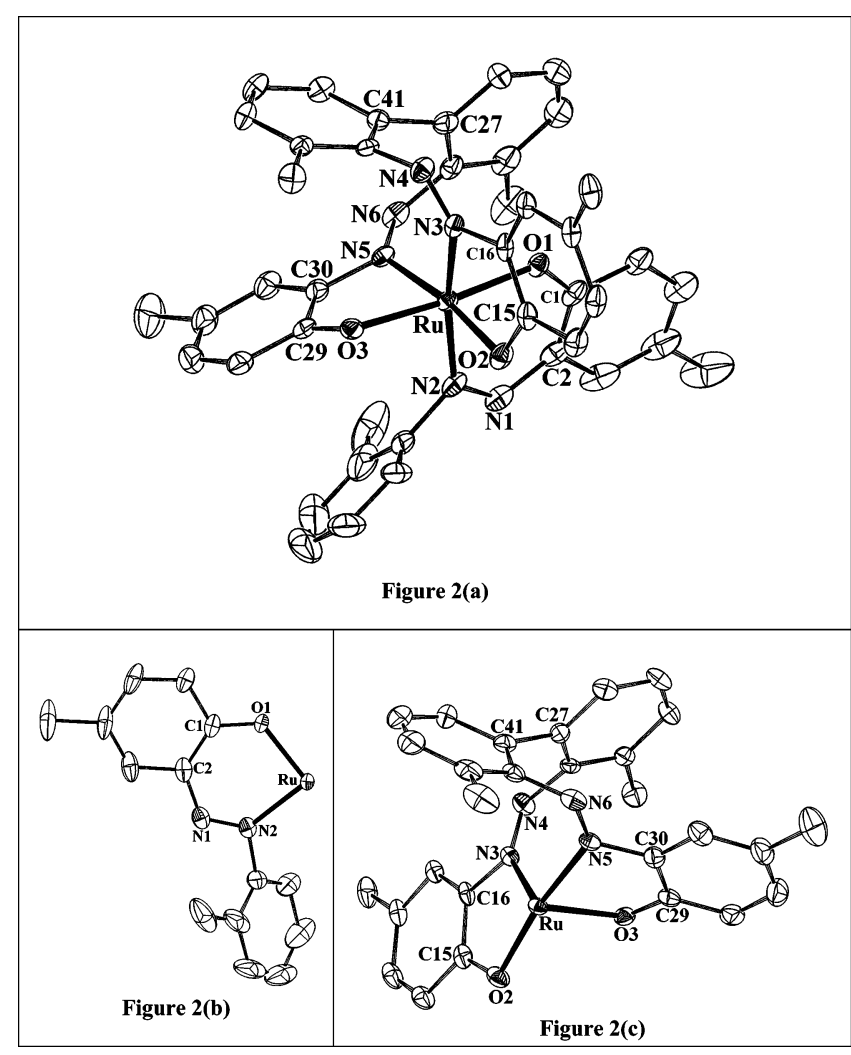

Figure 2. View of (a) the complex 2, (b) the coordinated 2-(2'-methylphenylazo)-4-methylphenolate ligand forming a six-membered N,O-chelate ring, and (c) the other two coordinated ligands that have undergone an unusual $\mathrm{C}-\mathrm{C}$ coupling.

chelate ring (Figure 2b), and the other two ligands have undergone a $\mathrm{C}-\mathrm{C}$ coupling reaction, via elimination of $\mathrm{H}_{2}$, and the coupled species is coordinated as a tetradentate ligand (V) forming a five-membered N,O-chelate ring, a ninemembered $\mathrm{N}, \mathrm{N}$-chelate ring, and another five-membered chelate ring (Figure 2c). The stereochemistry of this complex is meridional with reference to disposition of the metal-bound donor atoms. However, as compared to the earlier two structures, and particularly with reference to the uncoupled 2-(arylazo)phenolate ligand forming the six-membered chelate ring, the stereochemistry of complex $\mathbf{2}$ is different (Figure S4, Supporting Information). The observed bond parameters in complex 2 (Table 2) compare well with those in the earlier two structures.

The fact that the methyl group in the arylazo fragment of ligand $\mathbf{L}_{2}$ remained an innocent observer of the $\mathrm{C}-\mathrm{C}$ coupling reaction, which took place during the formation of complex 2 , has prompted us to study a similar reaction with a more sterically crowded 2-(arylazo)phenol, viz. 2-(2',6'dimethylphenylazo)-4-methylphenol $\left(\mathbf{L}_{3}\right)$, in which both the ortho positions of the phenyl ring in the arylazo fragment are blocked by methyl groups. So, in case a similar $\mathrm{C}-\mathrm{C}$ coupling reaction takes place as before, it must occur via elimination of $\mathrm{C}_{2} \mathrm{H}_{6}$. To check this, the reaction of ligand $\mathbf{L}_{3}$ with $\left[\mathrm{Ru}(\mathrm{dmso})_{4} \mathrm{Cl}_{2}\right]$ has been carried out as before, which has afforded a violet complex (3). The mass spectrum of complex 3 (Figure S5, Supporting Information) shows the molecular ion peak at 701, which is 87 units less than that expected for a tris chelated complex formed via loss of $\mathrm{C}_{2} \mathrm{H}_{6}$.
This clearly indicates that in case all the coordinated ligands in $\left[\mathrm{Ru}(\mathrm{dmso})_{4} \mathrm{Cl}_{2}\right]$ have been displaced during the synthetic reaction by three 2-(2',6'-dimethylphenylazo)-4-methylphenolate ligands, then the loss of some bigger fragment(s) from the 2-(2',6'-dimethylphenylazo)-4-methylphenolate ligand(s) must have taken place either permanently during the formation of complex $\mathbf{3}$ or transiently during the mass spectral measurements. The identity of complex $\mathbf{3}$ has been unveiled by its structure determination by X-ray crystallography. The structure (Figure 3$)$ shows that three 2- $\left(2^{\prime}, 6^{\prime}-\right.$ dimethylphenylazo)-4-methylphenols have interacted with the ruthenium center, but in different fashions. While two ligands are coordinated as a bidentate N,O-donor forming five- and six-membered chelate rings (Figure $3 b, c$ ), the third one has undergone cleavage across the $\mathrm{N}=\mathrm{N}$ bond leading to the generation of an iminophenolate fragment, which remains coordinated to the metal center as a bidentate N,O-donor ligand forming a five-membered chelate ring (Figure 3d). It may be relevant to note here that transition metal mediated $\mathrm{N}=\mathrm{N}$ cleavage reactions are of significant contemporary interest. ${ }^{17}$ Within the iminophenolate fragment, the $\mathrm{C}-\mathrm{O}$ and $\mathrm{C}-\mathrm{N}$ distances lie between those expected for localized single and double bonds, which clearly indicate that this ligand is coordinated in the iminosemiquinonate form $(\mathbf{V I}) .^{4 \mathrm{~d}}$<smiles></smiles>

Bond distances in the other two chelates compare well with those in similar chelates in the earlier structures. From the composition of complex $\mathbf{3}$, it is clear that ruthenium is in the +3 state in this complex. However, a magnetic susceptibility measurement shows that this complex is diamagnetic. The observed diamagnetism probably results from strong antiferromagnetic interactions between the unpaired electron on ruthenium and that on the iminosemiquinonate radical. The ${ }^{1} \mathrm{H}$ NMR spectrum of complex $\mathbf{3}$ shows six signals within $0.88-2.70 \mathrm{ppm}$ for the seven methyl groups present in it. Integration of these signals shows that of these six observed signals, the one at $2.33 \mathrm{ppm}$ corresponds to two methyl groups. This indicates that the local $C_{2}$ symmetry existing in the dimethylphenyl fragment of the uncoordinated ligand $\mathbf{L}_{3}$ is retained in one of the two coordinated ligands. From steric considerations, it appears that for the coordinated ligand forming the five-membered chelate ring (Figure 3b), free rotation of the dimethylphenyl fragment is still possible, and hence, the local $C_{2}$ symmetry may exist in this fragment.

(17) (a) Pratihar, J. L.; Maiti, N.; Chattopadhyay, S. Inorg. Chem. 2005 , 44, 6111. (b) Sridhara, M. B.; Srinivasa, G. R.; Gowda, D. C. Synth. Commun. 2004, 34, 1441. (c) Smith, J. M.; Lachicotte, R. J.; Holland, P. L. J. Am. Chem. Soc. 2003, 125, 15752. (d) Krogh-Jesperson, K.; Czerw, M.; Summa, N.; Renkema, K. B.; Achord, P. D.; Goldman, A. S. J. Am. Chem. Soc. 2002, 124, 11404. (e) Slaughter, L. M.; Wolczanski, P. T.; Klinckman, T. R.; Cundari, T. R. J. Am. Chem. Soc. 2000, 122, 7953. (f) Peters, J. C.; Cherry, J.-P. F.; Thomas, J. C.; Baraldo, L.; Mindiola, D. J.; Davis, W. M.; Cummins, C. C. J. Am. Chem. Soc. 1999, 121, 10053. (g) Liu, F.; Pak, E. B.; Singh, B.; Jensen, C. M.; Goldman, A. S. J. Am. Chem. Soc. 1999, 121, 4086. 


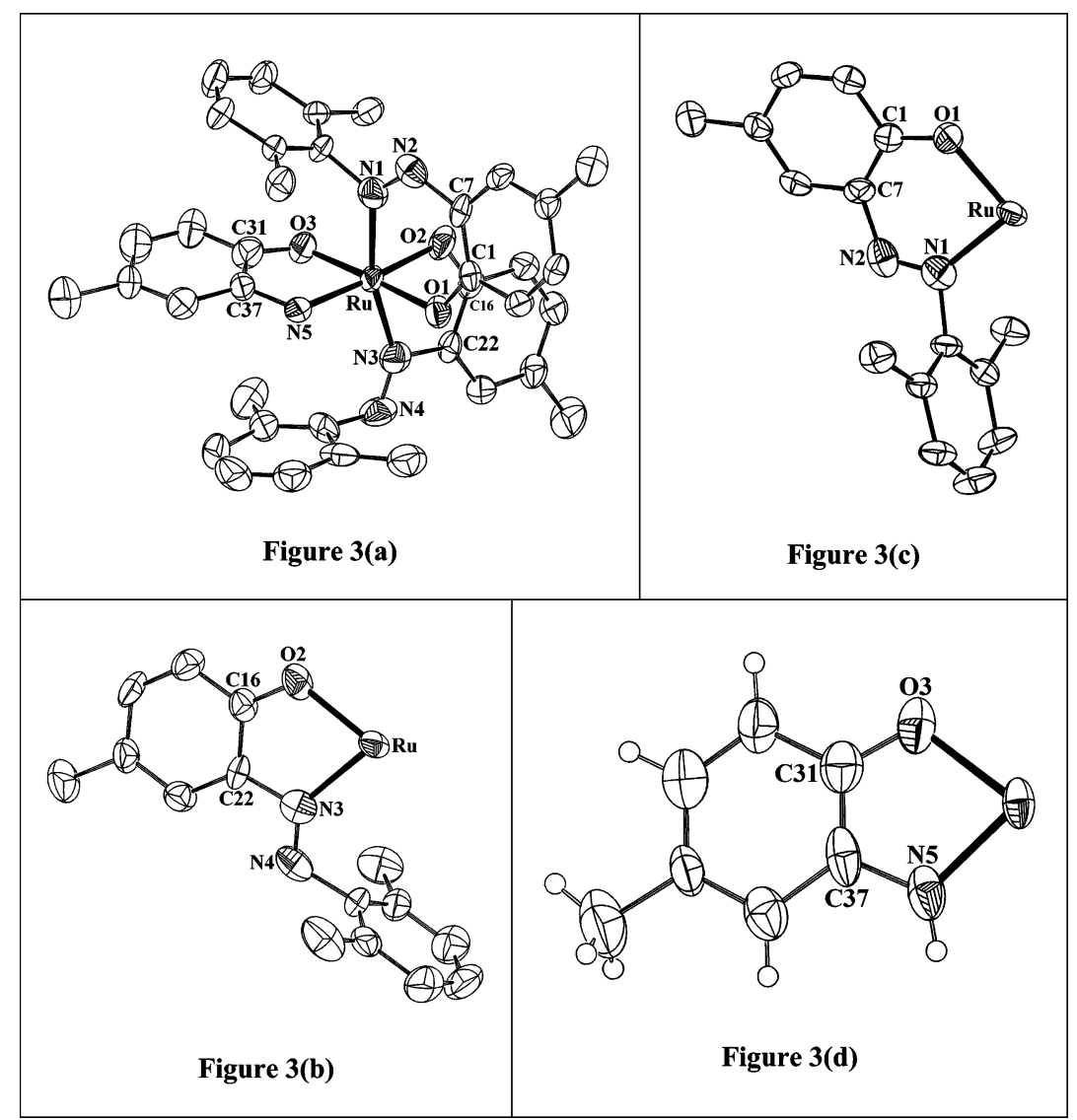

Figure 3. View of (a) the complex 3, (b) the coordinated 2-(2',6'-dimethylphenylazo)-4-methylphenolate ligand forming a five-membered N,O-chelate ring, (c) another ligand forming a six-membered $\mathrm{N}, \mathrm{O}$-chelate ring, and (d) the $\mathrm{N}=\mathrm{N}$ cleaved fragment of the ligand coordinated in the iminosemiquinonate form.

Table 3. Electronic Spectral and Cyclic Voltammetric Data of the Complexes

\begin{tabular}{|c|c|c|}
\hline compound & electronic spectral data ${ }^{a} \lambda_{\max }, \mathrm{nm}\left(\epsilon, \mathrm{M}^{-1} \mathrm{~cm}^{-1}\right)$ & cyclic voltammetric data ${ }^{a, b} E_{1 / 2},{ }^{c} V$ vs $\operatorname{SCE}\left(\Delta E_{\mathrm{p}},{ }^{d} \mathrm{mV}\right)$ \\
\hline $1-\mathrm{OCH}_{3}$ & $826(1400), 575^{e}(4500), 424(13800), 324(15400), 282^{e}(19500)$ & $0.85(72),-0.33(60)$ \\
\hline $1-\mathrm{CH}_{3}$ & $820(2000), 576^{e}(4300), 418(14900), 316(18600), 290$ (20300) & $0.91(70),-0.22(65)$ \\
\hline 1-H & $822(2200), 574^{e}(4300), 416(14500), 310^{e}(21600), 288(22500)$ & $1.00(77),-0.17(66)$ \\
\hline 1-Cl & $826(1800), 600^{e}(4000), 432(16700), 312(23700)$ & $1.05(70),-0.06(60)$ \\
\hline $1-\mathrm{NO}_{2}$ & $842(1500), 625^{e}(3100), 430(14400), 296$ (24500) & $1.16(65), 0.08(60)$ \\
\hline 2 & $854(1200), 574^{e}(3100), 438(9700), 312(13500)$ & $0.95(72),-0.25(78)$ \\
\hline 3 & $1418(410), 574$ (9400), 462 (7400), 402 (7000), $310^{e}(7800)$ & $0.48(68),-0.59(70)$ \\
\hline
\end{tabular}

${ }^{a}$ In acetonitrile. ${ }^{b}$ Supporting electrolyte, TBAP; scan rate $50 \mathrm{mV} \mathrm{s}^{-1} .{ }^{c} E_{1 / 2}=0.5\left(E_{\mathrm{pa}}+E_{\mathrm{pc}}\right)$, where $E_{\mathrm{pa}}$ and $E_{\mathrm{pc}}$ are anodic and cathodic peak potentials, respectively. ${ }^{d} \Delta E_{\mathrm{p}}=\left(E_{\mathrm{pa}}-E_{\mathrm{p}}\right) \cdot{ }^{e}$ Shoulder.

For the other coordinated ligand forming the six-membered chelate ring (Figure 3c), such rotation seems to be restricted. A singlet is observed at $11.55 \mathrm{ppm}$, which is assigned to the $\mathrm{N}-\mathrm{H}$ proton of the iminosemiquinonate fragment. All the aromatic proton signals are observed within $6.07-7.45 \mathrm{ppm}$.

Magnetic susceptibility measurements show that the five 1-R complexes as well as complex $\mathbf{2}$ are one-electron paramagnetic $\left(\mu_{\mathrm{eff}}=1.83-1.91 \mu_{\mathrm{B}}\right)$, which corresponds to the +3 state of ruthenium (low-spin d, ${ }^{5} S=1 / 2$ ) in these complexes. ESR spectra of these complexes have been recorded in a 1:1 dichloromethane/toluene solution at $77 \mathrm{~K}$. Each complex shows a rhombic ESR spectrum with three distinct signals $\left(\mathrm{g}_{1}, \mathrm{~g}_{2}\right.$, and $\mathrm{g}_{3}$; in order of decreasing magnitude). A selected spectrum is shown in Figure 4, and spectral data for all the complexes are given in Table 3. Rhombicity of the spectra reflects asymmetry of the electronic environment around ruthenium in these complexes.
When an octahedral geometry suffers from an axial distortion $(\Delta)$ the $t_{2}$ level splits into $a$ and $e$ components, and under the rhombic distortion (V), $e$ splits further (Figure 4). Spinorbit coupling causes additional changes in the energy gaps. Thus, two electronic transitions (transition energies $\Delta E_{1}$ and $\left.\Delta E_{2} ; \Delta E_{1}<\Delta E_{2}\right)$ are probable within these three levels. All these energy parameters have been computed (Table 3) using the observed $g$-values, the $g$-tensor theory of low-spin $\mathrm{d}^{5}$ complexes, ${ }^{18}$ and a reported method..$^{19}$ The axial distortion is found to be comparable to the rhombic one in all the complexes. ${ }^{20}$ The calculated values of $\Delta E_{1}\left(\sim 3700 \mathrm{~cm}^{-1}\right)$

(18) (a) Gri.th, J. S. The Theory of Transition Metal Ions; Cambridge University Press: Cambridge, 1961; p 364. (b) Bleany, B.; O'Brien, M. C. M. Proc. Phys. Soc. London 1956, 69, 1216.

(19) Bhattacharya, S.; Chakravorty, A. Proc. Indian Acad. Sci., Chem. Sci. 1985, 95, 159.

(20) The spin-orbit coupling constant $(\lambda)$ is taken to be $1000 \mathrm{~cm}^{-1}$ for complexed ruthenium(III). ${ }^{19}$ 
Halder et al.

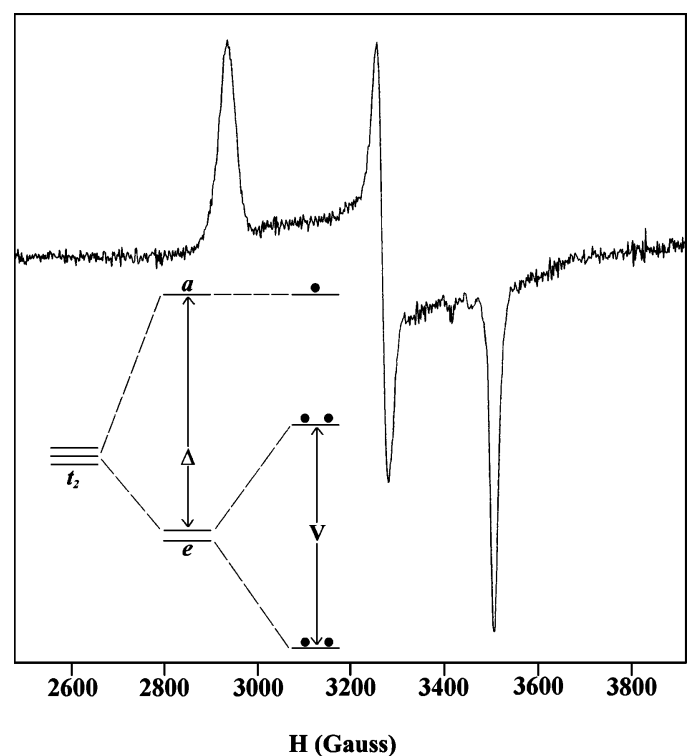

Figure 4. ESR Spectrum of complex 2 in 1:1 dichloromethane/toluene solution at $77 \mathrm{~K}$. Splitting of the $t_{2}$ levels is shown as an inset.

and $\Delta E_{2}\left(\sim 10000 \mathrm{~cm}^{-1}\right)$ indicate that two ligand-field transitions should take place in the near-infrared region, of which the lower energy transition could not be experimentally verified. However, the higher energy transitions have indeed been observed in the spectra of all the complexes near the predicted energy (vide infra). The ESR spectral data thus show that these complexes are significantly distorted from the ideal octahedral geometry, as was also indicated by their structure determinations.

Infrared spectra of all the complexes show several bands of different intensities in the $4000-400 \mathrm{~cm}^{-1}$ region. No attempt has been made to assign each individual band to a specific vibration. However, comparison with the spectra of the corresponding uncoordinated ligands shows that the phenolic $\mathrm{O}-\mathrm{H}$ stretch, observed near $3140 \mathrm{~cm}^{-1}$ in the uncoordinated ligands, is absent in all the complexes as expected. In the spectrum of complex $\mathbf{3}$, a sharp band is observed at $3273 \mathrm{~cm}^{-1}$, which is assigned to the $\mathrm{N}-\mathrm{H}$ stretch arising from the coordinated iminosemiquinonate fragment.

The 1-R, 2, and $\mathbf{3}$ complexes are found to be soluble in dichloromethane, chloroform, acetone, acetonitrile, etc., producing intense greenish-brown, brown, and violet solutions, respectively. Electronic spectra of these complexes have been recorded in acetonitrile solutions. Each complex shows several intense absorptions in the ultraviolet and visible region and a relatively weak absorption in the nearinfrared region (Table 4). The absorptions in the ultraviolet region are attributable to transitions within the ligand orbitals, and those in the visible region are probably due to ligandto-metal charge-transfer transitions. In the case of the 1-R and $\mathbf{2}$ complexes, the weak absorption in the near-infrared region is assignable to a ligand-field transition within the split $t_{2}$ orbitals (vide supra). In complex $\mathbf{3 b}$, a similar absorption at $1418 \mathrm{~nm}$ is attributable to a $\mathrm{d}-\mathrm{d}$ transition.

Electrochemical properties of all the complexes have been studied by cyclic voltammetry in acetonitrile solution $(0.1$ M TBAP). Each complex shows an oxidative response on
Table 4. ESR $g$-Values ${ }^{a}$ and Derived Parameters ${ }^{b}$ of the 1-R and 2 Complexes

\begin{tabular}{lccccccr}
\hline compound & $g_{1}$ & $g_{2}$ & $g_{3}$ & $\Delta / \lambda$ & $V / \lambda$ & $\Delta E_{1} / \lambda$ & $\Delta E_{2} / \lambda$ \\
\hline $\mathbf{1 - O C H}_{3}$ & 2.236 & 2.023 & 1.883 & 6.208 & 5.428 & 3.638 & 9.097 \\
$\mathbf{1 - C H}$ & 2.240 & 2.019 & 1.883 & 6.345 & 5.767 & 3.606 & 9.399 \\
$\mathbf{1 - H}$ & 2.235 & 2.019 & 1.893 & 6.759 & 6.325 & 3.736 & 10.081 \\
$\mathbf{1 - C l}$ & 2.231 & 2.015 & 1.887 & 6.471 & 5.952 & 3.639 & 9.614 \\
$\mathbf{1 - N O}_{2}$ & 2.221 & 2.008 & 1.900 & 7.283 & 7.289 & 3.778 & 11.078 \\
$\mathbf{2}$ & 2.297 & 2.065 & 1.924 & 8.279 & 7.783 & 4.500 & 12.301 \\
$\quad$ & \multicolumn{7}{c}{ In 1:1 dichloromethane/toluene solution at $77 \mathrm{~K}^{-}{ }^{b}$ Spin-orbit coupling } \\
constant $(\lambda)$ cormplexed $\mathrm{Ru}(\mathrm{III})$ is $\sim 1000 \mathrm{~cm}^{-1}$.
\end{tabular}

the positive side of SCE and a reductive response on the negative side. Voltammetric data are given in Table 4, and a selected voltammogram is shown in Figure S6 (Supporting Information). The oxidative response is tentatively assigned to $\mathrm{Ru}(\mathrm{III})-\mathrm{Ru}(\mathrm{IV})$ oxidation and the reductive response to $\mathrm{Ru}(\mathrm{III})-\mathrm{Ru}(\mathrm{II})$ reduction. The oxidative response is found to be quasi-reversible in nature, characterized by a lower cathodic peak current $\left(i_{\mathrm{pc}}\right)$ than the anodic peak current $\left(i_{\mathrm{pa}}\right)$. However, the reductive response is reversible in nature, characterized by a peak-to-peak separation $\left(\Delta E_{\mathrm{p}}\right)$ of $60-70$ $\mathrm{mV}$, which remains unchanged upon changing the scan rate, and the $i_{\mathrm{pa}}$ is almost equal to the $i_{\mathrm{pc}}$ as is expected for a reversible electron-transfer process. Potential of both the $\mathrm{Ru}(\mathrm{III})-\mathrm{Ru}(\mathrm{IV})$ oxidation and $\mathrm{Ru}(\mathrm{III})-\mathrm{Ru}(\mathrm{II})$ reduction in the 1-R complexes has been found to be sensitive to the nature of the substituent $\mathrm{R}$ in the arylazo fragment. The potential increases with increasing electron-withdrawing character of the substituent R. Plot of the redox potentials of the 1-R complexes versus $3 \sigma[\sigma=$ Hammett parasubstituent constant of $\mathrm{R} ;{ }^{21} \mathrm{OCH}_{3}=-0.27, \mathrm{CH}_{3}=-0.17$, $\mathrm{H}=0.00, \mathrm{Cl}=0.23$, and $\left.\mathrm{NO}_{2}=0.78\right]$ is found to be linear for both the couples (Figure S7, Supporting Information) with slopes $\left(\rho=\right.$ reaction constant of this couple $\left.{ }^{22}\right)$ of $0.09 \mathrm{~V}$ (for the $\mathrm{Ru}(\mathrm{III})-\mathrm{Ru}(\mathrm{IV})$ oxidation) and $0.12 \mathrm{~V}$ (for $\mathrm{Ru}(\mathrm{III})-$ $\mathrm{Ru}(\mathrm{II})$ reduction). This linear correlation of the redox potentials with the electronic nature $(\sigma)$ of the substituents with reasonable slopes $(\rho)$ clearly shows that a single substituent on the 2-(arylazo)phenolate ligand, which is several bonds away from the metal center, can still influence the metal-centered redox potential in a predictable manner.

\section{Conclusion}

The present study shows that the 2-(arylazo)phenols $\left(\mathbf{L}_{1}\right)$ can efficiently bind ruthenium(III) to afford stable complexes, containing a 2-(arylazo)phenolate ligand forming a sixmembered chelate ring and a tetradentate ligand formed from two 2-(arylazo)phenols via an unusual $\mathrm{C}-\mathrm{C}$ coupling linking the two ortho carbons of the phenyl rings in the arylazo fragment. Blocking of both the ortho positions, which can potentially undergo the $\mathrm{C}-\mathrm{C}$ coupling, by methyl groups results in the cleavage of the $\mathrm{N}=\mathrm{N}$ bond of one ligand. Interactions of the 2-(arylazo)phenols $\left(\mathbf{L}_{\mathbf{1}}\right)$ and some related ligands with other platinum metal compounds are currently under investigation.

(21) Hammett, L. P. Physical Organic Chemistry, 2nd ed.; McGraw-Hill: New York, 1970.

(22) Mukherjee, R. N.; Rajan, O. A.; Chakravorty, A. Inorg. Chem. 1982, 21,785 . 
Acknowledgment. The authors thank the reviewers for their comments and suggestions, which were helpful in preparing the revised version of the manuscript. Financial assistance received from the Department of Science and Technology [Grant SR/S1/IC-15/2004] is gratefully acknowledged. The authors thank Prof. A. Chakravorty of the Department of Inorganic Chemistry, Indian Association for the Cultivation of Science, Kolkata, and Dr. Jitendra K. Bera of the Department of Chemistry, Indian Institute of Technology, Kanpur, for the ESR spectra. M.G.B.D. thanks EPSRC (UK) and the University of Reading for funds for the Image Plate System. S.H. thanks the University Grants Commission, New Delhi, for her fellowship [Grant 10-2(5)2004(1)-E.U.II].
Supporting Information Available: Structure of complex 1-NO $\mathbf{N O}_{2}$ (Figure S1), models for the linkage isomers of the tris chelates (Figure S2), mass spectrum of complex 2 (Figure S3), comparison of stereochemistry of complex 1-R with that of complex 2 (Figure S4), mass spectrum of complex 3 (Figure S5), cyclic voltammogram of 1-H (Figure S6), least-squares plots of $E_{1 / 2}$-values of $\mathrm{Ru}(\mathrm{III})-\mathrm{Ru}(\mathrm{IV})$ and $\mathrm{Ru}(\mathrm{III})-\mathrm{Ru}(\mathrm{II})$ couples versus $3 \sigma$ for the 1-R complexes (Figure S7), selected crystal data and data collection parameters for complex 1-NO $\mathbf{N O}_{2}$ (Table S1), selected bond distances and bond angels for complex $\mathbf{1 - N \mathbf { N } _ { 2 }}$ (Table S2), and X-ray crystallographic data in CIF format. This material is available free of charge via the Internet at http://pubs.acs.org.

IC060689U 